\title{
Exploring Agri Business Potential in Tripura through Fruits and Vegetable Production
}

\author{
Saddam Hossen Majumder* and Nivedita Deka
}

Department of Agricultural Economics, Faculty of Agriculture, Assam Agricultural University, Jorhat-785013, Assam, India

*Corresponding author: shmajumder@aau.ac.in

\begin{abstract}
The agro climatic condition of Tripura offers immense potential for production of number of tropical and sub tropical fruits and vegetables. Major horticulture produce comprises fruits $(48.6 \%)$ and vegetables (48.3\%) (2013-14). Fruit and vegetable are important component of the food items of the state. The production of fruits and vegetables provide gainful employment for small farmers and agricultural labour throughout the year. Foreign exchange can be earned by exporting the raw and processed form of fruits and vegetables. The production of both fruits and vegetables are increasing significantly at a growth of 3.86 and 13.36 per cent over the last decades. In this study an attempt was made to estimate the marketable surplus of fruits and vegetables for exploring the agri business potentiality. The secondary data on production of fruits and vegetable in the state over the decade (2001-2014) were collected from Economic Review of Tripura. Compound growth rate and regression analysis was done to achieve the objective. The supply of fruits and vegetables was estimated considering the future production using regression method of forecasting. Similarly, demand for fruits and vegetables were estimated considering the recommended amount of fruits $(100 \mathrm{gm})$ and vegetable $(150 \mathrm{gm})$ per person per day in the state. An amount of 10 per cent was assumed as post harvest loss. The results showed that there is significant marketable surplus of both fruits and vegetables in the coming four years (upto 2021) showing the possibility of value addition to this surplus amount through establishing processing units in the state that would help to boost farmers' income and employment. However, government initiatives along with growers and processors interest needs to be developed for exploring the vast potentiality of this sector in the state.
\end{abstract}

Keywords: Fruits, vegetables, marketable surplus, forecast, processing, Tripura

Tripura is the third smallest State of India which became a fully fledged state on the $21^{\text {st }}$ January, 1972 and located in the North Eastern Region. The State is surrounded by the neighbouring country Bangladesh on its south, west and north. The warm and humid climatic condition of Tripura is perfect for producing plenty of fruits, spices and vegetables. Tripura produces about $1.62 \mathrm{mMT}$ of horticulture produce from an area of $0.14 \mathrm{~m}$ ha (2013-14). Major horticulture produce comprises fruits $(48.6 \%)$ and vegetables (48.3\%) (2013-14). The State is still the largest producer of True Potato Seed (TPS) in the country. Till 2014-15, about 1,37,750 ha area has been under cultivation of fruits $(71,180 \mathrm{ha})$, plantation crops (19,000 ha), vegetables $(39,110 \mathrm{ha})$, spices (8460 ha) and flowers ( 290 ha).With enormous demand of fresh flower, floriculture has become a blooming business in the state. Similarly the fruits and vegetable processing sector can contribute to the state economy, if explored properly. In this paper an attempt is made to estimate the marketable surplus of fruits and vegetables for exploring the agri business potentiality.

\section{METHODOLOGY}

Secondary data on major fruits and vegetables were used to compute analysis. Secondary information was collected from the published journals, bulletins and official records of districts and blocks. Requirement of fruits and vegetable are considered based on RDA as $100 \mathrm{gm}$ fruits/adult/day and vegetable $150 \mathrm{gm} / \mathrm{adult} /$ day. The marketable surplus 
was calculated as the difference between availability and requirement.

\section{Estimation of growth rates by exponential trend equation}

The data were analyzed by fitting the exponential function to study the trends in area, production and productivity of major fruits and vegetables in the state. Accordingly, Compound Growth Rates (CGR) of area, production and productivity of fruits and vegetables were computed using the exponential function.

The exponential function form:

$$
\mathrm{Y}=\mathrm{ab} \mathrm{b}^{\mathrm{t}}
$$

Or, $\ln y=\ln a+t \ln b$

Compound Growth Rate (CGR) was computed by using the formula:

$$
\text { CGR }=\text { Antilog }(b-1) \times 100
$$

Where, $\mathrm{y}=$ time series data on area/production/yield of fruits and vegetables

$$
\begin{aligned}
& b=\text { regression coefficient } \\
& t=\text { time period in years }
\end{aligned}
$$

\section{Estimation of Co-efficient of Variation}

To examine the stability with respect to area, production and yield of the crops, mean, standard deviation and coefficient of variation were worked out for the four different periods of fruit and vegetables crops.

$$
\begin{gathered}
\text { Coefficient of variation }=\text { Standard Deviation } / \\
\text { Mean } \times 100
\end{gathered}
$$

\section{RESULTS AND DISCUSSION}

From the Table 1, it is observed that there is a positive growth of all the fruits crops that is being considered for the study. The production of fruits and vegetables provide gainful employment for small farmers and agricultural labour throughout the year. The production of both fruits and vegetables are increasing significantly over the last decades. The overall growth rate in area of different fruits and vegetable crops revealed that the maximum growth rate per annum was observed in case of Pineapple and mango being nearly 10.20 per cent per and 9.61 per cent per annum as compound rate followed by lemon 9.31 per cent per annum, banana, 8.78 per cent per annum, Orange, 8.58 per cent per annum, Winter vegetables (cabbage, cauliflower, tomato, radish etc.,), 8.47, guava, 7.05 , litchi, 6.77 , summer vegetables (pumpkin, ash gourd, bottle gourd, brinjal), 5.58, jackfruit, 0.37 per cent per annum, respectively. Banana constitutes $17.1 \%$ of total production of fruits in the state. During 2013-14, 960 MT of banana have been traded in organized markets with average price of ₹ $11.21 / \mathrm{Kg}$. Citrus forms $7.38 \%$ of total production of fruits in the state. Tripura accounts for $1.0 \%$ of total production of oranges in the country with productivity of 5.4 MT/ha. Tripura is the fourth largest producer of pineapple in the country. State accounts for $8.2 \%$ of the total production of pineapple in country with productivity of $15.0 \mathrm{MT} / \mathrm{ha}$. Cabbage accounts for about $10.0 \%$ of total production of vegetables in the state with productivity of 26.17 MT/ha. During 2013-14, 1432 MT of cabbage have been traded in organized markets with average price of ₹ 15.33/ $\mathrm{Kg}$. Cauliflower forms $6.7 \%$ of total production of vegetables in the state with productivity of $20.50 \mathrm{MT} / \mathrm{h}$. Potato constitutes about $19.8 \%$ of total production of vegetables in the state with productivity of 17.64 MT/ha. During 2013-14, 3189 MT of potato have been traded in organized markets with average price of ₹ $20.24 / \mathrm{Kg}$.

It could be inferred from the Table 2 that the supply of fruits and vegetables was estimated considering the future production using regression method of forecasting. Similarly, demand for fruits and vegetables were estimated considering the recommended amount of fruits $(100 \mathrm{gm})$ and vegetable $(150 \mathrm{gm})$ per person per day in the state. An amount of 10 per cent was assumed as post harvest loss. The supply of fruits and vegetables in the state at present (2017) is calculated to be 749.073 th tonnes and 892.96 th tonnes, respectively. Considering the recommended requirement of fruits $(100 \mathrm{gm} /$ per person/day) and vegetables per person per day $(150 \mathrm{gm})$, the demand for fruits and vegetables in the state for the current year (2017) is calculated to be 116.56 th tonnes and 174.84 th tonnes, respectively. It is noted that the overall supply of fruits and vegetables in the state is higher than the current demand reflecting the state as fruits surplus (569.26 th tonnes) and vegetables surplus 
Table 1: Growth and Coefficient of Variation of major fruits and vegetables (\%)

\begin{tabular}{ccccccc}
\hline Crops & \multicolumn{2}{c}{ Area } & \multicolumn{2}{c}{ Production } & \multicolumn{2}{c}{ Yield } \\
\cline { 2 - 7 } & CGR & CV & CGR & CV & CGR & CV \\
\hline Litchi & $6.77^{* * *}$ & 28.60 & $6.13^{* * *}$ & 26.00 & -0.60 & 7.76 \\
Mango & $9.61^{* * *}$ & 52.10 & $17.84^{* * *}$ & 95.21 & $7.51^{* * *}$ & 38.20 \\
Pineapple & $10.20^{* * *}$ & 46.15 & $5.68^{* * *}$ & 25.85 & $-4.10^{* * *}$ & 19.41 \\
Guava & $7.05^{* * *}$ & 52.82 & $13.52^{* * *}$ & 69.89 & $6.03^{* * *}$ & 25.04 \\
Orange & $8.58^{* * *}$ & 46.27 & $5.91^{* * *}$ & 29.66 & $-2.46^{*}$ & 31.57 \\
Jackfruit & 0.37 & 10.05 & $1.16^{*}$ & 8.99 & 0.78 & 8.28 \\
Banana & $8.78^{* * *}$ & 43.31 & 4.25 & 39.50 & -4.16 & 27.31 \\
Lemon & $9.31^{* * *}$ & 49.72 & $9.27^{* * *}$ & 45.58 & -0.03 & 7.99 \\
Winter vegetables & $8.47^{* * *}$ & 22.60 & $14.23^{* * *}$ & 36.31 & $5.31^{* * *}$ & 14.45 \\
Summer vegetables & $5.58^{* * *}$ & 15.44 & $12.36^{* * *}$ & 31.85 & $6.41^{* * *}$ & 17.18 \\
\hline
\end{tabular}

* Significant at 10\%, ** significant at 5\%, ${ }^{* * *}$ significant at 1\% significance level

Table 2: Demand and Supply of fruits and vegetables in Tripura

\begin{tabular}{ccccccc}
\hline \multirow{2}{*}{ Year } & \multicolumn{2}{c}{ Availability } & \multicolumn{2}{c}{ Requirement } & \multicolumn{2}{c}{ Net marketable surplus } \\
\cline { 2 - 7 } & Fruits & Vegetables & Fruits & Vegetables & Fruits & Vegetables \\
\hline 2017 & 749.073 & 892.96 & 116.56 & 174.84 & 569.26 & 646.31 \\
2018 & 785.591 & 1012.31 & 118.19 & 177.28 & 600.66 & 751.53 \\
2019 & 825.405 & 1147.61 & 119.83 & 179.75 & 635.01 & 871.07 \\
2020 & 868.951 & 1300.99 & 121.50 & 182.25 & 672.70 & 1006.86 \\
2021 & 916.722 & 1474.86 & 123.20 & 184.79 & 714.17 & 1161.06 \\
\hline
\end{tabular}

(646.31 th tonnes), respectively. This surplus covers the probable post harvest losses of vegetables upto $10-20 \%$. Assuming the similar trend, the demand and supply forecast for fruits in 2021 is estimated to be (123.20 th tonnes and 916.722 th tonnes) and vegetables 184.80 th tonnes and 1474.86 th tonnes, respectively implying that the future supply exceeds future demand in Tripura showing the state as fruits and vegetables secured with a surplus of 714.17 th tonnes and 1161.06 th tonnes, respectively. The results showed that there is significant marketable surplus of both fruits and vegetables in the coming four years (upto 2021) showing the possibility of value addition to this surplus amount through establishing processing units in the state that would help to boost farmers' income and employment.

Table 3 shows that there have been significant improvements over the years especially in terms of area expansion of different crops, respective production volumes and in adoption of modern technologies. A linear growth trend in production of major components of horticulture i.e. fruits, vegetables and spices in the last two five year plans, can be well derived from the table indicating average annual growth rate of production of these crops during $10^{\text {th }}$ and $11^{\text {th }}$ Plan.

Table 3: Trend in Growth

\begin{tabular}{|c|c|c|c|}
\hline Crop & $\begin{array}{l}10^{\text {th }} \text { plan } \\
(2002-07)\end{array}$ & $\begin{array}{l}11^{\text {th }} \text { plan } \\
(2007-12)\end{array}$ & $\begin{array}{l}12^{\text {th }} \text { plan } \\
(2012-17)\end{array}$ \\
\hline Fruits (\%) & 3.50 & 5.20 & 8.20 \\
\hline Vegetables (\%) & 6.80 & 7.75 & 8.75 \\
\hline Spices (\%) & 1.52 & 6.50 & 7.70 \\
\hline
\end{tabular}

\section{CONCLUSION}

The study revealed that there is a positive growth rate in area and production of all fruit and vegetables crops in the state. The yield growth rate further reveals that there has been a substantial change in the yield of all fruit and vegetables crops. However, variability in area and yield are quite high in all fruit and vegetables crops, which affects the volume of production. It is suggested that the surplus supply is converted to value added products that would call for establishment of cold storage and processing industry which will ensure both enhanced farm 
income and increased employment opportunities. However, to make the vegetables supply sustainable in the state, both public and private interventions and efforts must be continued. Further, government initiatives along with growers and processors interest needs to be developed for exploring the vast potentiality of this sector in the state.

\section{REFERENCES}

GoI. 2015. Agricultural Statistics at a Glance, 2015. Directorate of Economics and Statistics, Ministry of Agriculture, Government of India.
GoT. 2014. Statistical Abstract 2014. Directorate of Economics and Statistics, Government of Tripura, Tripura.

GoT. 2015. Economic Review of Tripura 2014-15. Department of Agriculture, Government of Tripura, Tripura.

GoT. 2016. Annual state plan 2015-16. Government of Tripura, Tripura. 